\title{
MIG1 overexpression causes flocculation in Saccharomyces cerevisiae
}

\author{
C. S. Shankar, M. S. Ramakrishnan and S. Umesh-Kumar
}

Author for correspondence: S. Umesh-Kumar. Tel: +91 821 23539. Fax: +91 821521713.

Department of Food Microbiology, Central Food Technological Research Institute, Mysore570013 , India

\begin{abstract}
MIG1, encoding a $\mathrm{C}_{2} \mathrm{H}_{2}$ zinc-finger repressor protein involved in carbon catabolite repression, was found to play a role in non-sexual flocculation of Saccharomyces cerevisiae. Disruption of MIG1 in a flocculent mutant strain of NCYC 227, resulted in a non-flocculent phenotype. Expression of MIG1 on a $2 \mu$ pRS426 vector in a non-flocculent strain, YM 4134, caused flocculation; MIG1 on a high-copy-number LEU2-d plasmid caused intense flocculation in the same strain. Mutations in the SSN6 and TUP1 genes confer a flocculent phenotype in non-flocculent strains of $S$. cerevisiae, and it has been shown that Mig1 can tether the Ssn6p-Tup1p complex to the regulatory regions of glucoserepressible genes. Mutations in tup1 in a MIG1 background caused flocculation while double mutants of TUP1 and MIG1 did not flocculate. Based on these results, a model for the role of MIG1 in flocculation gene regulation is proposed.
\end{abstract}

Keywords: flocculation, regulation, MIG1, SSN6-TUP1

\section{INTRODUCTION}

Yeast flocculation and cell sedimentation to the bottom of the fermenter are desirable properties of $S$. cerevisiae strains used in industrial fermentations (Stratford, 1992). Flocculation might serve as a useful tool in modern biotechnological processes such as the production of heterologous proteins from yeast, since it is a cheap and easy way to separate the cells from culture fluids, thus facilitating further downstream processing. Flocculation in all yeast genera appears to conform to the Lectin-like Hypothesis (Miki et al., 1982), and a mannose-specific flocculation lectin has recently been identified (Shankat \& UmeshKumar, 1994).

Flocculation is under genetic control and may be transferred by mating, cytoduction or electrofusion (Stratford, 1994). Much interest has centred on FLO1, a dominant gene sufficient for flocculation (Teunissen et al., 1993a). It is located on chromosome I and a full sequence has been published (Watari et al., 1994). Another gene, FLO5, is also known to be dominant and is located on chromosome VIII (Teunissen et al., 1995b). Some non-flocculent strains if mutated in certain genes become flocculent. These genes include TUP1 (Lipke \& Hull-Pillsbury, 1984) which is allelic to SFL2 (Fujita et al, 1990), CYC9 (Rothstein \& Sherman, 1980) and SSNG allelic to CYC8 (Trumbly, 1988). Both TUP1 and SSNG encode proteins which form a repressor complex in a regulatory cascade (Keleher $e t$ al., 1992). Many of these non-flocculent strains contain intact FLO1 sequences (Teunissen et al., 1995a).
Thus, the induction of flocculation in these strains suggested the presence of one or more flocculation genes that were silent in the corresponding wild-type strains. In contrast, some strains with FLO1 flocculate in the presence of intact TUP1 and SSN6 genes, and it has been shown that in these strains flocculation is insensitive to the TUP1/SSN6 regulatory cascade (Teunissen et al, 1995a). Thus, much remains unknown about the regulation of flocculation at the molecular level. In this paper, we present evidence to indicate constitutive overexpression of $M I G 1$ in flocculating strains as a cause for flocculation in $S$. cerevisiae.

\section{METHODS}

Strains and growth media. YM 4134 (MATa MIG1 TUP1 ura3 bis3 leu2 ade 2 lys 2 trp1) and YM 4230 (MATa mig1::LEU2 TUP 1 ura 3 bis 3 leu 2 ade 2 lys 2 trp 1 ) are two strains of $S$. cerevisiae obtained from the collection of Dr M. Johnston, Department of Genetics, Washington University School of Medicine, St Louis, MO, USA. Flocculent strains of S. cerevisiae NCYC 227 and NCYC 1119 and non-flocculent strains NCYC 431 and SD 164 are cultures maintained in this laboratory. The original cultures were obtained from the National Collection of Yeast Cultures (NCYC), UK, and I,abatt Breweries, Canada. The cultures were routinely grown in yeast extract/peptone/dextrose (YPD) broth or agar. For some of the experiments, dextrose was replaced with raffinose or glycerol in the medium. Yeast minimal medium with necessary amino acid selection was used for genetic studies.

Measurement of flocculation. Flocculation was determined by an assay method described by Nagatajan \& Umesh-Kumar 
(1990) with the following modifications. Cells washed with $250 \mathrm{mM}$ EDTA and resuspended in deionized water to $2.0 \times 10^{8}$ cells $\mathrm{ml}^{-1}$ were distributed in tubes. Flocculation was initiated by the addition of $1 \mathrm{ml} 250 \mathrm{mM} \mathrm{CaCl}_{2}$ solution and $\mathrm{OD}_{660}$ was determined after $5 \mathrm{~min}$ of settling. The percentage of cells in the supernatant was proportional to the difference in the mean optical density between the experimental tubes and the control tubes without added $\mathrm{CaCl}_{2}$.

For studies on the effect of inhibitors on flocculation, the assay was carried out with cells suspended in $100 \mathrm{mM}$ Tris $/ \mathrm{HCl}$ buffer, $\mathrm{pH} 8 \cdot 0$. Heat-killed cells were used for sugar-inhibition tests (Stratford \& Assinder, 1991). The effect of Pronase E on flocculation was studied after incubating the cells for $15 \mathrm{~min}$ in Tris/ $\mathrm{HCl}$ buffer at $37^{\circ} \mathrm{C}$.

Cloning. The MIG1 gene on plasmid pBM2220 ( $p$ MIG1; Nehlin \& Ronne, 1990) was used for overexpression studies. This plasmid contained a LEU2 defective gene for high-copynumber and UR $A 3$ for selection. Yeast strain YM 4134 was transformed with this plasmid and the transformants were selected on uracil-less glucose plates. They were then replicated on leucine-less plates or broth for high-copy plasmids. For normal-copy expression of MIG1, the $\sim 3.2 \mathrm{~kb} X b a \mathrm{I}-$ HindIII fragment of MIG1 (for restriction map see Nehlin \& Ronne, 1990) was cloned into the yeast centromere vector, pRS316, linearized with the same enzymes. Eschericbia coli strain DH5a was transformed with the cloned plasmid by electroporation. The plasmid prepatation obtained from the transformed bacteria was confirmed for the presence of this construct by restriction digestion and electrophoresis. A portion of this plasmid stock was used to transform the yeast strain. The $M I G 1$ gene located within the NotI-HindIII fragment of the above construct was subcloned into the yeast $2 \mu$ plasmid (pRS426) and used as the plasmid for moderate level expression of $M I G 1$.

Yeast strains were transformed with $10 \mu \mathrm{g}$ plasmid DNA using the lithium acetate procedure (Ito et al., 1983). For quantification of flocculation phenotype, the transformed yeast strains were grown in yeast minimal broth with approptiate amino acid selection, and intensity of flocculation was assayed as described above. In all these experiments, controls consisted of yeast strains transformed with plasmids containing no $M I G 1$ gene.

mRNA isolation and Northern analysis. Total mRNA was isolated from late exponential phase cultures (Kohren \& Domdey, 1993) by passing through an oligo(dT) cellulose spun column (Pharmacia) previously equilibrated with high-salt buffer [10 mM Tris/HCl (pH 7.5), 0.2\% SDS, 5 mM EDTA; $0.5 \mathrm{M} \mathrm{NaCl}$. The mRNA in the preparation was determined by measuring $\mathrm{OD}_{260}$ using a Shimadzu spectrophotometer for Northern dot blot analysis. Identical concentrations of mRNA from strains of $S$. cerevisiae were applied as dots on to the GeneScreen nylon membrane. The bound MIG1 mRNA on the membrane was detected using $\sim 1.5 \mathrm{~kb} M I G 1$ DNA probe labelled with digoxigenin 11-UTP. The DIG DNA labelling and detection kit of Boehringer Mannheim was used according to the manufacturer's instructions. The probe was hybridized at $68^{\circ} \mathrm{C}$ for $12 \mathrm{~h}$ with gentle shaking. The probe used for Northern analysis was the MIG1 gene amplified by PCR. The two primers synthesized for $M I G 1$ amplification, 5'-AGTGTCTAACGTTGATGA-3' and 5'-G'TCCA'TG'TGTGGGAAGGGC-3', were based on the published MIG1 gene sequence (Nehlin \& Ronne, 1990).

Genetic studies. A leu2 mutant of NCYC 227, obtained by UV irradiation and confirmed for the mutation by complementation with a LEU2 centromere plasmid, was used for MIG1 disruption, MIG1 was distupted in this strain (mig $1:: L E U 2)$ by transformation with the XbaI-HindIII fragment of the MIG1 disruptor plasmid pBM2169 (Nehlin \& Ronne, 1990). TUP1 was disrupted in the non-flocculent mig1 strain of $S$. cerevisiae (YM 4230) using the HindIII fragment of the TUP1 disruptor plasmid pBM2004 (tup1::UR A3). The desired strains were identified by 2-deoxyglucose resistance and clumpy growth (mig1 and tup1 phenotypes, respectively).

\section{RESULTS AND DISCUSSION}

The strain of $S$. cerevisiae YM 4134 used in this study was a non-flocculent haploid. Distuption of TUP1 in this strain (tup1::UR $A 3$ ) resulted in mutants that were flocculent. This result was similar to that previously reported (Lipke \& Hull-Pillsbury, 1984). Table 1 shows a comparison on the effect of inhibitors of flocculation in a tup1 strain in relation to the brewery strains NCYC 1119 and NCYC 227. The inhibitory effects were similar in all strains and specific inhibition of flocculation by mannose and $\alpha$-methyl D-mannoside suggested the strains to conform to FLO1, FLO5 or FLO8 phenotypes (Stratford \& Assinder, 1991; Stratford, 1992). At $10 \mu \mathrm{g}$ Pronase $\mathrm{E} \mathrm{ml} \mathrm{m}^{-1}$, a concentration that almost completely inhibited flocculation in NCYC 227, focculation of NCYC 1119 and tup 1 mutants was 26 and $84 \%$ of the control values, respectively. This reflected the flocculation intensity of the strains: growth experiments showed higher flocculation intensity with the tup 1 strain compared with NCYC 1119 which was more flocculent compared with NCYC 227 (Shankar \& Umesh-Kumar, 1994). Increased flocculation intensity appeared to reflect the synthesis of more flocculation proteins as indirectly shown by the inhibitory effects of mannose and $\alpha$-methyl D-mannoside. Mannose and $\alpha$-methyl $\mathrm{D}$-mannoside at $500 \mathrm{mM}$ completely inhibited flocculation in NCYC 227 and 1119, but caused only about $60 \%$ flocculation inhibition in the tup1 strain. The antibody raised against the flocculation protein of NCYC 227 reacted with NCYC 1119 (Shankar \& Umesh-Kumar, 1994), and also cross-reacted with the tup1 mutant (data not shown). Thus, it appeared that the flocculation gene in the strain YM 4134 was silent due to its sensitivity to the TUP1 regulatory cascade. However, some dispersion of flocculation in the tup1 strain due to $200 \mathrm{mM} \mathrm{NaCl}$ differentiated it from the other strains used in this study.

TUP1, together with SSN6, is known to be involved in the repression of many important yeast genes. Keleher $e t$ al. (1992) suggested that Tup1p-Ssn6p locates the wide variety of genes that it represses by recognizing the specific DNA-bound proteins present at each promoter. A strong candidate for such a protein was Miglp (Multicopy Inhibitor of $G A L$ genes), which has been shown to bind to regions of the promoter required for glucose-dependent repression of SUC2 and GAL 4, and is required in addition to $\mathrm{Ssn6p}$ and Tup1p for complete repression of both genes (Nehlin \& Ronne, 1990; Nehlin et al., 1991; Griggs \& Johnston, 1992). An earlier report had shown flocculation identical to that of FLO1 in $S$. cerevisiae when $\mathrm{C}_{2} \mathrm{H}_{2}$ zinc-finger $\mathrm{HTLV}-1$ Tax-transactivator protein was overexpressed (Kramer et al., 1990). Since MIG1p is also a $\mathrm{C}_{2} \mathrm{H}_{2}$ zinc-finger DNA-binding 
Table 1. Effect of inhibitors on flocculation

Values are means of triplicate determinations. The maximum variation between tubes was $10 \%$, with mean standard errors of $3 \%$. Control values ranged from 84 to $91 \%$ aggregated cells.

\begin{tabular}{|c|c|c|c|}
\hline \multirow[t]{2}{*}{ Inhibitor } & \multicolumn{3}{|c|}{ Percentage of control flocculation } \\
\hline & tup1 & NCYC 1119 & NCYC 227 \\
\hline None & 100 & 100 & 100 \\
\hline $100 \mathrm{mM}$ Tris $/ \mathrm{HCl}$ buffer $(\mathrm{pH} 8.0)$ & 100 & 100 & 100 \\
\hline $200 \mathrm{mM} \mathrm{NaCl}$ & 86 & 100 & 100 \\
\hline $250 \mathrm{mM}$ EDTA & 0 & 0 & 0 \\
\hline $10 \mu \mathrm{g}$ Pronase $\mathrm{E} \mathrm{ml}^{-1}$ & 84 & 26 & 10 \\
\hline $100 \mu \mathrm{g}$ Pronase $\mathrm{E} \mathrm{ml}^{-1}$ & 30 & 2 & 0 \\
\hline $1 \mathrm{mg}$ Pronase $\mathrm{E} \mathrm{ml}^{-1}$ & 0 & 0 & 0 \\
\hline $500 \mathrm{mM}$ Glucose & 96 & 98 & 98 \\
\hline $500 \mathrm{mM}$ Galactose & 96 & 100 & 100 \\
\hline $500 \mathrm{mM}$ Mannose & 45 & 0 & 0 \\
\hline $500 \mathrm{mM} x$-Methyl D-mannoside & 40 & 0 & 0 \\
\hline
\end{tabular}

Table 2. Effect of MIG1 overexpression on flocculation

\begin{tabular}{|llcc|}
\hline Strain & $\begin{array}{c}\text { MIGI on } \\
\text { plasmid }\end{array}$ & $\begin{array}{c}\text { Plasmid copy } \\
\text { no. }\end{array}$ & $\begin{array}{c}\text { Flocculation } \\
\text { intensity* }\end{array}$ \\
\hline YM 4230 & pRS316 & $1-2$ & - \\
YM 4134 & pRS426 & $10-40$ & ++ \\
YM 4134 & pBM2220 & 100200 & ++++ \\
\hline
\end{tabular}

* - , Non-flocculent; ++++ , highly flocculent.

protein with domains for Tuplp and Ssn6p (Treitel \& Carlson, 1995), we proceeded to test the importance of this protein in flocculation. When TUP1 was disrupted (tup 1::UR A3) in the non-flocculent mig1 strain (YM 4230) the double mutants were non-flocculent. Disruption of $M I G 1$ in a flocculent leu2 mutant of NCYC 227 also resulted in a non-flocculent phenotype. These results showed an important role for $M I G 1$ in flocculation.

In another experiment, the role of $M I G 1$ gene dosage on yeast flocculation was determined. MIG1 was overexpressed at two levels in strain YM 4134. High-copyexpression of $M I G 1$ was obtained using the gene cloned in a LEU2-d plasmid (pBM2220), MIG1 cloned in a $2 \mu$ multicopy vector pRS426 when expressed in this yeast strain (YM 4134) resulted in moderate levels of the gene. As a control, MIG1 was cloned in a centromere vector, pRS316, and expressed in a mig1 strain (YM 4230). While $M I G 1$ in normal copy-numbers did not influence flocculation, increasing the $M I G 1$ gene dosage caused an increase in the intensity of flocculation in YM 4134 (Table 2). Heavy flocculation in YM 4134 due to overexpression of $M I G 1$ on a LEU2-d plasmid affected the growth of the yeast in glucose broth. It could be argued that titration of Ssn6p/Tup1p repressors due to overexpression of $M I G 1$ caused flocculation similar to the TUPf and SSNG mutations. However, it is unlikely that this is the cause for flocculation because increasing the gene dosage of $M I G 1$
Table 3. Effect of inhibitors on flocculation in relation to $M I G 1$ gene dosage

Values are means of triplicate determinations. The maximum variation between tubes was $3 \%$, with a mean standard error of $2 \%$. Control values ranged from 96 to $100 \%$ aggregated cells. Figures in parentheses indicate MIG1 copy number. Plasmid pRS316 was not tested because it had no effect on flocculation intensity (sce Table 2).

\begin{tabular}{|c|c|c|}
\hline \multirow[t]{2}{*}{ Inhibitor } & \multicolumn{2}{|c|}{$\begin{array}{c}\text { Flocculation intensity (\%) } \\
\text { with } M I G I \text { expressed on } \\
\text { plasmid: }\end{array}$} \\
\hline & $\begin{array}{c}\text { pRS426 } \\
(10-40)\end{array}$ & $\begin{array}{l}\text { pBM2220 } \\
(100-200)\end{array}$ \\
\hline None & 100 & 100 \\
\hline $250 \mathrm{mM}$ EDTA & 0 & 0 \\
\hline $1 \mathrm{mg}$ Pronase $\mathrm{E} \mathrm{ml}^{-1}$ & 23 & 82 \\
\hline $3 \mathrm{mg}$ Pronase $\mathrm{E} \mathrm{ml}^{-1}$ & 0 & 20 \\
\hline $500 \mathrm{mM}$ Mannose & 70 & 85 \\
\hline $1 \mathrm{M}$ Mannose & 5 & 18 \\
\hline $500 \mathrm{mM} \alpha$-Methyl D-mannoside & 60 & 80 \\
\hline $1 \mathrm{M} \alpha$-Methyl D-mannoside & 0 & 10 \\
\hline
\end{tabular}

at two levels in YM 4134, having a single copy of SSNG and TUP7, resulted in an additive response with respect to flocculation intensity. It appeared that MIG1 overexpression caused increased synthesis of the flocculation protein, since the concentration of mannose or $\alpha$-methyl $\mathrm{D}$-mannoside required to cause inhibition of flocculation in such strains was higher, and more Pronase $\mathrm{E}$ was needed to destroy the flocculation protein in these cells (Table 3).

A role for $M I G 1$ gene dosage as a cause of differential flocculation intensity in the wild-type strains NCYC 227 
(a)

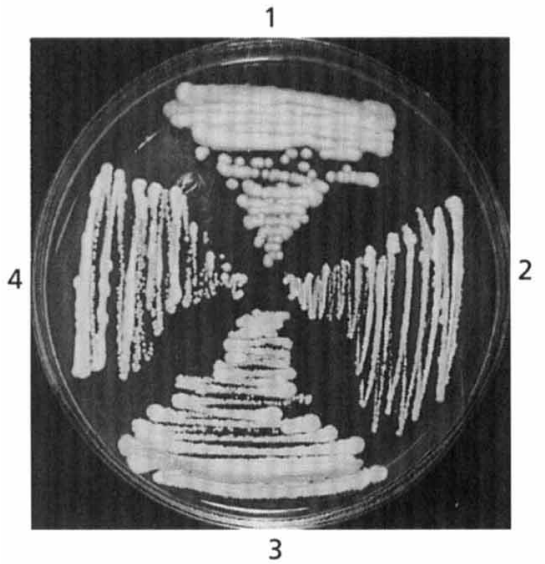

(b)

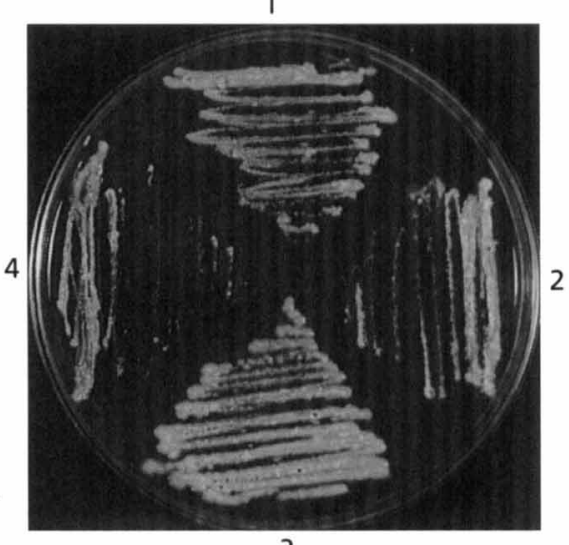

3

Fig. 1. Growth of non-flocculent (1, NCYC 431; 3, SD 164) and flocculent (2, NCYC 227; 4, NCYC 1119) strains of S. cerevisiae after $24 \mathrm{~h}$ on YP glucose (a) and YP raffinose (b) agar plates.

and 1119 was also studied. MIG1 overexpression has been shown to cause repression of $S U C 2$ (invertase) gene expression (Nehlin \& Ronne, 1990). Growth experiments with flocculent and non-flocculent strains showed slow growth of the flocculent strains NCYC 227 and 1119 when raffinose was used as the carbon source, while growth on glucose was unaffected (Fig. 1). When the corresponding invertase levels were determined (Table 4), it was found that reduced invertase levels in flocculent strains affected their growth on raffinose. These observations were further confirmed by Northern analysis which indicated higher concentrations of $M I G 1 \mathrm{mRNA}$ in the cells of flocculent strains compared with nonflocculent strains (data not shown). This suggested constitutive overexpression of MIG1 in flocculent strains. Growth of the highly flocculent strain NCYC 1119 was extremely slow in YP glycerol broth. This could be due to the effect on glycerol utilization of MIG1 overexpression. These results could also explain variations in flocculation among strains of S. cerevisiae (Stratford \& Carter, 1993), with some strains showing higher flocculation intensity compared with the others (Stratford \& Assinder, 1991).
Table 4. Whole-cell invertase and MIG1 mRNA in strains of $S$. cerevisiae

Invertase levels are given as a percentage $(100 \%=14 \cdot 45 \mathrm{U})$. Invertase was assayed in whole cells as described by Trumbly (1988) and specific activicy was expressed as $\mu \mathrm{mol}$ glucose formed $\min ^{-1}$ (mg whole-cell protein) $)^{-1}$. For derermination of whole-cell protein concentration, $0.5 \mathrm{ml}$ cell suspension was taken in a test tube and boiled for $5 \mathrm{~min}$ with $0.5 \mathrm{ml} 1 \mathrm{M} \mathrm{NaOH}$. Total protein was estimared in the lysed suspension by the Lowry method. -, Non-flocculent; ++++ , highly focculent.

\begin{tabular}{|rcc|}
\hline Strain & Invertase (\%) & Degree of flocculation \\
\cline { 2 - 3 } 431 & 100 & - \\
227 & 69 & +++ \\
1119 & 40 & ++++ \\
\hline
\end{tabular}

FLO genes may encode cell-surface flocculation lectins (Teunissen et al., 1993b). Direct activation of these genes by MIG1 could be postulated since Mig1 has stretches of glutamine-rich residues similar to the activator protein $S p 1$ (Nehlin \& Ronne, 1990). This appears improbable in the light of the report of the absence of transcriptional activation by glutamine residues of $S p 1$ (Ponticelli et al., 1995). Hence $M I G 1$ has a probable repressor function in flocculation gene expression. Thus, only positive regulation of the flocculation structural gene by an activator proposed by Stratford (1992) can be explained in relation to the Migl activity. FLO8 as an activator of genes involved in flocculation has been suggested recently (Kabayashi et al., 1995). Since Mig1p is a repressor protein, a direct repression of the activator is inconceivable because $M I G 1$ disruption in flocculent $S$. cerevisiae caused the appearance of a non-flocculent phenotype. It can be presumed that the activator is controlled by an active repressor whose function is repressed by $M I G 1$. In this model, it is conceivable that the number of $M I G 1$ transcripts determine the degree of inhibition of the repressor as has been shown in this study on differential MIG1 expression, resulting in an additive response in respect to flocculation. However, further experimental evidence is required to substantiate this model.

\section{ACKNOWLEDGEMENTS}

The authors thank Dr Mark Johnston, Department of Genetics, Washington University School of Medicine, St Louis, MO, USA, for strains and plasmids used in this work. We thank the Director of the Institute and Professor H. S. Shetty, Department of Biotechnology, University of Mysore, India, for facilities. C.S.S. thanks CSIR, New Delhi, India, for a Research Fellowship Award.

\section{REFERENCES}

Fujita, A., Matsumoto, S., Kuhara, S., Misumi, Y. \& Koboyashi, H. (1990). Cloning of the SFL2 gene: its disruption results in pleiotropic phenotype characteristic for tup1 mutants. Gene 89, 93-99. 
Griggs, D. W. \& Johnston, M. (1992). Regulatory expression of the $G A L 4$ activator gene in yeast provides a sensitive genetic switch for glucose repression. Proc Natl Acad Si $i$ US A 88, 8597-8601.

Ito, H., Fukuda, Y., Murata, K. \& Kimura, A. (1983). Transformation of intact yeast cells tteated with alkali cations. J Bacteriol 153, 163-168.

Kabayashi, O., Suda, H., Ohtani, T. \& Sone, H. (1995). Molecular cloning and characterization of yeast flocculation gene FLO8. Yeast 11,558 .

Keleher, C. A., Redd, M. J., Schultz, J., Carlson, M. \& Johnson, A. D. (1992). SSNG-TUP1 is a general repressor of transcription in yeast. Cell 68, 709-719.

Kohren, K. \& Domdey, H. (1993). Preparation of high molecular weight RNA. Metbols Envymol 194, 398-405.

Kramer, R. A., Tomchak, L., Ruben, S. M. \& Rosen, C. A. (1990). Expression of the HTI.V-1 tax transactivation factor in yeast: correlation between phenotypic alterations and tax functions in higher eukaryotes. AIDS Res Hum Retroviruses 6, 1305-1309.

Lipke, P. N. \& Hull-Pillsbury, C. (1984). Flocculation of Saccharomyces cerevisiae TUP1 mutants. J Bacteriol 159, 797-799.

Miki, B. L. A., Poon, N. H., James, A. P. \& Seligy, V. L. (1982). Possible mechanism for focculation interactions governed by gene FLOt in Sacharomyces cerevisiae. J Bacteriol 150, 878-889.

Nagarajan, L. \& Umesh-Kumar, S. (1990). Antigenic studies on the flocculating brewers yeast, Saccharomyces cerevisiae NCYC 227. J Gen Microbiol 136, 1747-1751.

Nehlin, J. O. \& Ronne, H. (1990). Yeast MIG1 repressor is related to the mammalian early growth response and Wilms' tumour finger proteins. E:MBO J 9, 2891-2898.

Nehlin, J. O., Carlberg, M. \& Ronne, H. (1991). Control of yeast $G A L$ genes by $M I G 1$ repressor: a transcriptional cascade in the glucose response. EMBO J 10, 3373-3377.

Ponticelli, A. S., Pardee, T. S. \& Struhl, K. (1995). The glutamine rich activation domain of human $S_{p} 1$ does not stimulate transcription in Sacbaromyces cerevisiae. Mol Cell Biol 35, 456-464.

Rothstein, R. J. \& Sherman, F. (1980). Genes affecting the expression of cytochrone $c$ in yeast genetics mapping and gene interactions. Genetics $94,871-889$.
Shankar, C. S. \& Umesh-Kumar, S. (1994). A surface lectin associated with flocculation in brewing strains of Sactbaromyces cerevisiae. Microbiology 140, 1097-1101.

Stratford, M. (1992). Yeast flocculation: reconciliation of physiological and genetic view points. Yeast 8, 25-38.

Stratford, M. (1994). Another brick in the wall? Recent developments concerning the yeast cell envelope. Yeast 10, 1741-1752.

Stratford, M. \& Assinder, S. (1991). Yeast flocculation: Flo1 and NewFlo phenotypes and receptor structure. Yeast 7, 559-574.

Stratford, M. \& Carter, A. T. (1993). Yeast flocculation: lectin synthesis and activation. Yeast 9, 371-378.

Teunissen, A. W. R. H., van den Berg, J. A. \& Steensma, H. Y. (1993a). Physical localization of the flocculation gene FLO1 on chromosomes of Saccharomyces cerevisiae. Yeast 9, 1-10.

Teunissen, A. W. R. H., Holub, E., van der Hucht, J., van den Berg, J. A. \& Steensma, H. Y. (1993b). Sequence of the open reading frame of the FLO1 gene from Saccharomyces cerevisiae. Yeast 9 , 423-427.

Teunissen, A. W. R. H., van den Berg, J. A. \& Steensma, H. Y. (1995a). Transcriptional regulation of flocculation genes in $S a c-$ charomyces cerevisiae. Yeast 11, 435-446.

Teunissen, A. W. R. H., van den Berg, J. A. \& Steensma, H. Y. (1995b). Localization of the dominant flocculation genes FLOS and FLO8 of Saccharonyces cerevisiae. Yeast 11, 735-745.

Treitel, M. A. \& Carlson, M. (1995). Repression by SSN6-TUP1 is directed by $M I G 1$, a repressor/activator protein. Proc Natl Acad Soi USA 92, 3132-3136.

Trumbly, R. J. (1988). Cloning and characterization of the CYC8 gene mediating glucose repression in yeast. Gene 73, 97-111.

Watari, J., Takata, Y., Ogawa, M., Sahara, H., Koshino, S., Onnela, M. L., Airaksinen, U., Jaatinen, R., Pentilla, M. \& Keranen, $\mathbf{S}$. (1994). Molecular cloning and analysis of the flocculation gene FLO1. Yeast 10, 211-225.

Williams, F. E. \& Trumbly, R. J. (1990). Characterization of TUP1, a mediator of glucose reptession in Saccharomyces cerevisiae. Mol Cell Biol 10, 6500-6511.

Received 23 February 1996; revised 10 May 1996; accepted 20 May 1996. 